\title{
Doing business for a "higher loyalty"? How Swedish transnational corporations neutralise allegations of crime
}

\author{
Isabel Schoultz ${ }^{1} \cdot$ Janne Flyghed $^{2}$
}

Published online: 10 May 2016

(C) The Author(s) 2016. This article is published with open access at Springerlink.com

\begin{abstract}
In recent years, two Swedish companies have been a focus of substantial media attention: TeliaSonera and Lundin Petroleum. The defensive strategies employed by these two businesses to deal with allegations of crime will be analysed on the basis of Stanley Cohen's theoretical work on processes of denial and neutralisation techniques. This paper will focus on a particular form of denial, namely the appeal to higher loyalties, whereby the businesses try to explain why they have been doing business despite the risks that this has involved. The paper links together the companies' communications with the contexts in which they occur and the structures that might be expected to influence how the companies choose to frame their communications. The presence of the corporations in areas where crimes have been committed is not denied, but implicatory denials are employed to justify the corporations' operations by referring to the societal benefits of their business activities. When the corporations frame their businesses as contributing to development, democracy and peace in the countries in which they operate, the corporations use well-known discourses that underline Swedish or Nordic generosity, helpfulness and decency. Thus, the analysis also draws on post-colonial theory and the image of the Nordic countries as being particularly "good" in relation to the rest of the world.
\end{abstract}

\section{Introduction}

Over recent years, a number of Swedish businesses have been accused of engaging in criminal activities both in the media and via legal proceedings. From a criminological perspective, the strategies employed by these businesses when defending themselves against allegations of crime are interesting, since they provide knowledge about the

Isabel Schoultz

isabel.schoultz@soclaw.lu.se

1 Sociology of Law Department, Lund University, Box 42, SE-221 00 Lund, Sweden

2 Department of Criminology, Stockholm University, SE-106 91 Stockholm, Sweden 
concrete reasoning of businesses with regard to the boundaries of their responsibility for human rights and the environment. We use the crime concept to refer not only to actions covered by the penal code, but also to non-punishable violations of human rights and the environment. This type of extension of the crime concept is often employed as the point of departure in studies of harms to people, animals and the environment that have been caused by states or businesses, since a stricter definition of crime excludes many forms of behaviour that are damaging to society [1-3].

Two Swedish companies have been a focus of substantial media attention: TeliaSonera and Lundin Petroleum. In 2012, the so-called Uzbekistan affair was uncovered, involving senior officers at TeliaSonera who are currently under suspicion of having committed bribery offences. Lundin Petroleum was accused by several international NGOs of participating in crimes against humanity in Sudan, which led to the initiation of an ongoing police investigation in Sweden into violations of international law. These businesses have been chosen for the study in part because they have ties to Sweden and have been publicly accused of engaging in criminal activities, and partly because they differ from one another with respect to ownership structure, sector, and the types of crime of which they have been accused. The point of departure for the analysis is how these businesses' defences are expressed, primarily in the media but also in press releases and other official information produced by the corporations themselves.

The defensive strategies employed by the businesses will be analysed on the basis of Stanley Cohen's [4-6] theoretical work on processes of denial and neutralisation techniques. The businesses' strategies for responding to allegations of crime are not viewed as responses to individual incidents but rather as an ongoing process whose objective is to legitimise their actions [6]. This paper will focus mainly on a particular form of denial whereby the businesses try to explain why they have been doing business despite the risks that this has involved. For example, it is known that the risk of becoming involved in human rights violations is related to the nature of the industry, with corporations that are active in the field of oil and gas exploitation being particularly associated with human rights violations in conflict zones [7]. Cohen [5] distinguishes one particular form of denial that may be highly applicable here, which involves justifying events by referring to an appeal to a higher loyalty, e.g. the "national interest", thus invoking a transcendent ideology. Higher loyalties that may be relevant in relation to businesses include economic interests, such as profit maximisation and loss minimisation, but also the societal benefits associated with new investment and corporate expansion aimed at increasing market share. Huisman [7] acknowledges that the appeal to higher loyalties may also involve references to the positive influence of business activities in a given region, e.g. in the form of economic development and democracy.

The paper links together the companies' communications with the contexts in which they occur and the structures that might be expected to influence how the companies choose to frame their communications. In a period when the concept of Corporate Social Responsibility (CSR) has become well-known, businesses have become increasingly concerned about appearing to be ethical and responsible [8, 9]. Defence mechanisms do not arise in a vacuum but may rather be assumed to be accepted within a social and cultural context $[6,10]$. From an international perspective, Sweden's positive human rights reputation (see $[8,11]$ makes the Swedish context particularly interesting. A society's institutional and social structures constitute a central foundation for the 
defence strategies utilised by businesses. Structures of this kind may in themselves make it easier for businesses to commit crimes and at the same time provide support for the defence strategies that they employ. Thus the article aims to answer the following questions: In what ways do the two companies accused of crimes appeal to higher loyalties? How might the Swedish social and cultural context affect the ways in which this particular defence mechanism is used?

\section{Previous research}

Following a rediscovery of the criminologist Edwin Sutherland's [12] pioneering work on white-collar crime, the literature on corporate crime developed from the mid-1970s [13-15]. At this time, the research was primarily focused on the effects of corporate behaviour on the physical environment. It was not until the beginning of the 1990s that attention came to be directed at the human rights consequences of corporate actions [16]. Since then, there has been an increase in the amount of attention focused on the human rights records of businesses, and in particular those of large multi-national corporations. The areas of Sutherland's research that touched upon crimes committed in the interests of businesses, and upon organisational aspects of crime, subsequently came to be labelled corporate crime $[17,18]$. The research in this field has shown that crimes committed by businesses have caused enormous harm and costs for both people and the environment (e.g. [2, 9, 19]).

Despite the improved research situation, research on the strategies employed by businesses in connection with allegations of crime is limited. There are however a number of criminological studies that are of relevance to the current research. A number of scholars have studied how individuals employ different types of neutralisation techniques in order to motivate white-collar crime [20,21]. These studies differ from the current paper however, in that they focus on processes associated with the individual offender.

Other studies have had a more organisational focus. Proceeding from the research on neutralisation techniques, Benoit [22] studied how two corporations (Exxon and Union Carbide) defended their reputations in connection with catastrophic accidents that they had caused. Mathiesen [23] has identified different forms of isolation techniques that have been used by oil companies in connection with disasters, intended to pulverise the incident. A study by Whyte [24] that had originally intended to focus on how corporate leaders defended and neutralised the decision to establish their businesses in occupied Iraq, came in practice to take a different turn. In the context of interviews with the corporate leaders, Whyte discovered that they did not feel there was anything that needed either to be defended or neutralised, that they were "just doing business". What Whyte's study reveals is that, in order for neutralisations to become necessary, the business's representatives must first perceive that there is something that they need to defend themselves against, allegations of some kind. This is the case in connection with the two companies, Lundin Petroleum and TeliaSonera, which are studied in this paper. Building further on the foundations laid by these studies, this paper works to develop a more detailed understanding of the strategies employed by businesses to defend themselves against allegations of crime by studying and comparing the defence mechanisms that the two companies in focus have employed in a number of different 
forums. In the next section we will turn to the actual allegations that have been made against them.

\section{The two Swedish transnational corporations}

\section{Lundin petroleum}

The Swedish Lundin Oil (later Lundin Petroleum) corporation signed a contract with the Sudanese Government to extract oil from an area that at the time was not under government control. The area had been in the grip of civil war for a number of decades and the land was primarily under the control of a rebel group known as the SPLA (Sudan People's Liberation Army). This rebel group was now standing in the way of Lundin's drilling operations and thus making it impossible both for the company and the Sudanese regime to make money out of the as yet unexplored oil field. In order to make continued prospecting work possible, those living in the area had to be moved. The Sudanese regime stated that the resettlement only related to those parts of the civilian population that could be viewed as having links to the rebels, although in reality the focus was directed at all those living in the area. Militias were armed (which in several cases included child soldiers) and, together with the Sudanese army, these groups expelled people who happened to be in what would subsequently be labelled "Block 5 A" as soon as this area was taken over by Lundin Oil. The evacuation of Block 5 A became violent, and resulted in both the rape and murder of individuals who found themselves in the area. Over the following years, several human rights organisations reported on violations of international law in Sudan and on the involvement of the Swedish oil company [25-27].

However, it was not until 2010, when the European Coalition on Oil in Sudan (ECOS), an umbrella organisation for around 50 voluntary organisations, presented a report entitled "Unpaid Debt - the Legacy of Lundin in Block 5A, Sudan 19972003" [28] that the accusations against the company resulted in a substantial amount of media attention. Since that time, the Swedish International Public Prosecution Office has been investigating whether any Swedish citizen may have committed violations of international law in connection with the genocide and expulsions in Sudan. To date no individuals have been notified that they are suspected of having committed offences [29].

When Lundin Petroleum was confronted with the allegations, the company first denied any involvement. Two individuals figured in central roles in the context of the media reporting. One of these central figures was one of the sons of the company's founder, Adolf Lundin. This son, Ian Lundin, was at the time, and remains today, the chairman of the company's board of directors. Another of Adolf Lundin's sons, Lukas, who also sits on the board of directors, also participated in the media debate that followed the publication of the allegations, but not to the same extent as his brother. The other person who was assigned a central role in this debate, however, was the wellknown Swedish politician, Carl Bildt, who had been a member of the company's board of directors for a while, but who had resigned his position upon being appointed Sweden's Foreign Minister in 2006. 


\section{TeliaSonera}

The public monopoly Televerket was transformed into a public sector joint stock company in 1993 and was renamed Telia. In 2002 the company merged with the Finnish company Sonera. At the present time, the Swedish government remains the company's principal shareholder with almost 40 percent of the company's shares. Since 2007, TeliaSonera has been conducting business in Central Asia. A large part of these operations have been located in Uzbekistan, a country that according to Transparency International [30] has one of the highest levels of corruption in the world. Uzbekistan has been controlled by the authoritarian President Islam Karimov and his family since 1990, and has over the years shown itself to have very little respect for human rights [31]. As a result of the regime's human rights record, TeliaSonera's presence in Uzbekistan has been criticised by both human rights organisations and parts of the Swedish media since as early as 2008 .

In 2012, one of Sweden's leading investigative journalism TV-shows presented a number of revelations about TeliaSonera's activities in Central Asia. To begin with, these revelations focused on how the company was participating in the regime's interception of communications among individuals opposed to the regime. They then moved on to look at the $3 \mathrm{G}$-licensing process in Uzbekistan. Information was presented describing extensive monetary transactions to a letter-box entity, Talikant, which was linked to the Karimov family. Talikant was owned by an assistant to Gulnara Karimova, the president's daughter, and is calculated to have earned over 200 million Euros between 2007 and 2010 as a result of the licensing deal [32]. Hundreds of millions of Euros that are linked to the deal have been frozen in accounts in Switzerland into which money had been paid by TeliaSonera. Over 21 million Euros have also been frozen at the Swedish bank Nordea in Stockholm, as have other assets in the form of luxury properties in France.

TeliaSonera's dealings in Central Asia, and in Uzbekistan in particular, have attracted a substantial amount of media attention and have led to demands for the company to present answers. Suspicions regarding corruption offences and money laundering have become increasingly powerful and in 2012, prosecutors decided to class the activities as bribery. A criminal investigation has been initiated to examine suspected bribery offences among former TeliaSonera staff and the investigation is still ongoing at the time of writing.

\section{Theoretical framework}

In the classic article Techniques of Neutralisation, Sykes and Matza [33] explain how neutralisations are employed by young offenders in order to deny the immorality of certain actions. Proceeding from Sykes and Matza's work, Stanley Cohen [6] describes the use of neutralisation techniques in relation to state violations of human rights, and uses these techniques as a tool to deconstruct official discourses that have been produced in connection with allegations of crime. Cohen's framework, unlike Sykes and Matza's, primarily focuses on the use of neutralisation techniques as an official response subsequent to crimes having been committed and allegations made. Cohen [6] argues, however, that the use of neutralisation techniques can also be seen to some 
extent prior to crimes being committed, in which case they function as a means of making it possible to commit violations while at the same time reducing culpability. In a similar way, the defence mechanisms identified in this paper will not only be viewed as neutralisations of individual events, but also as an overarching and continuously ongoing process intended to legitimise the continuing work of the business as a whole. The defence mechanisms that are employed are situated in a broader context and are utilised precisely because they are perceived as being publicly accepted [6]. We have found Cohen's work on denials and techniques of neutralisation to constitute an appropriate framework for the analysis of these defence mechanisms, and we have therefore chosen to expand on Cohen's research by applying his concepts to the field of business.

Cohen [6] identifies three overarching strategies, which together form a spiral of denial, and which may appear separately or in sequence. In the first, literal denial, the event itself is denied, e.g. by the state claiming that "nothing has happened". For companies, the same strategy might involve similar statements, or claims that "we have not used bribes" for example. In situations of this kind, those in power depict journalists and human rights organisations as being selective in their reporting and as working on the basis of a hidden political agenda. The second form of denial, interpretative denials, occurs when the media and human rights organisations show that the event really has taken place. In these situations, those responsible must retreat and admit that the event has happened, but they then defend their actions by attempting to reformulate the description of the problem in various ways and by denying the extent of what has happened. Another strategy found in this phase involves attempting to shift responsibility to something else, such as civil war, a drugs war or ethnic conflicts. In the third form of denial, implicatory denial, there is no attempt to deny either the facts or the conventional interpretation of these facts. Instead the focus is directed at contesting the implications of what has happened. This type of denial involves for example, accounts that justify the event by referring to a higher loyalty [4, 6] which will constitute the principal focus of this paper. Cohen [6], p. 103) points out that in practice the three forms of denial seldom run in sequence, and that they more often appear simultaneously. Within these three principal forms of denial, Cohen [6] identifies seven different techniques, of which five are drawn from Sykes and Matza's [33] theory (denial of responsibility, denial of injury, denial of the victim, condemnation of the condemners and appeal to higher loyalties), while two were developed specifically in relation to political actors (denial of knowledge and moral indifference).

The theoretical framework provided by Cohen will be elaborated on and extended in this paper. On the one hand, the defensive strategies may function differently for businesses than for states, and on the other, the Swedish context may define boundaries for the types of response to allegations that are possible. Allegations and responses should be viewed as a dynamic process, in which what it is that needs to be neutralised and defended is constantly changing [24]. Thus, it will be necessary to situate the defence mechanisms used by the Swedish corporations in a social and cultural context. For example, the corporations refer directly and indirectly to the self-image of Sweden, which is usually associated with political democracy, social welfare and economic equality (see [34]). One of the core components of the Swedish self-image is a strong focus on social justice and human rights (see [35]). To be able to understand the accounts used by the corporations and the frames in which they are embedded, the 
analysis also draws on post-colonial theory and the image of the Nordic countries as being particularly "good" in relation to the rest of the world [36, 37]. The post-colonial approach problematises the ways in which the world is perceived through a "western" discourse, in which the North is perceived as being civilised, modern and developed, in contrast to the South (or what is more often described as the "Third World" or "developing countries") [38]. The relevance of the post-colonial perspective emerged during our analysis of the data and is employed as a complement to Cohen's theory on denial in order to better explain the framing of the corporate defensive discourse.

\section{Method and material}

Manifestations of defence strategies will here be approached by means of frame analysis, i.e. an analysis of how the phenomenon in question is framed. Frame analysis was first presented by Goffman [39], but its current forms bear little resemblance to the original [40]. Frames can be understood as "underlying structures of belief, perception, and appreciation" ([41], p. 23). The struggle over the naming and framing of a situation includes not only the way problems are represented but also the solution [41].

Frame analysis involves a focus on discourses, which may be described as the language, key concepts and categories that are used to frame a given issue [42]. Discourses are viewed here as not only including language use, but also social practice - in the current case not only what the businesses write and say but also how they act within the discourse. By contrast with more customary analyses of discourses, frame analysis focuses on capturing the conscious formulation of statements [43].

The material in which the businesses' defences are expressed is mainly comprised of dominant national newspapers, radio and TV-interviews, but also includes press releases and other official information produced by the corporations. The selection was performed in two steps.

First, an initial sample of material was obtained by means of a systematic search in Mediearkivet, a digital news archive which contains all of the major Swedish daily newspapers, provincial newspapers and magazines, journals and periodicals, and also Swedish media content that has only been published online. Mediearkivet has a manual search database, and our searches were specified using keywords and dates. For both of the corporations, the keywords employed were the name of the corporation, the crimes of which they have been accused and the countries in which the alleged crimes have taken place. ${ }^{1}$ The searches were limited to a two-year period from the time at which suspicions of criminal activity were first made public in relation to each company. ${ }^{2}$ Only articles in which the companies themselves make statements of some kind were chosen.

\footnotetext{
${ }^{1}$ The search terms employed for TeliaSonera were: TeliaSonera AND Uzbekistan AND mut*. Muta is the Swedish word for bribe. The asterisk $\left(^{*}\right)$ enables the search engine to find various different endings of the word. The search terms employed for Lundin Petroleum were: Lundin Petroleum AND Sudan AND folkrätt*. Folkrättsbrott is the Swedish term for crimes against international law.

${ }^{2}$ For TeliaSonera, the systematic search included news articles published between 18/09/2012 and 17/09/ 2014. The corresponding period for the search conducted in relation to Lundin Petroleum was from 07/06/ 2010 to $06 / 06 / 2012$.
} 
Second, during the reading of the media content generated by the systematic search in Mediearkivet, additional relevant material was identified. This included, for example, references to company press releases, letters to shareholders, radio reports, television clips, other forms of interviews with company representatives and also news articles published prior to and after the period covered by the systematic search. We decided to locate and include this material in the analysis for two main reasons. The first of these was that it would make our sample less dependent on the search words used in the systematic search (search words always involve a risk that relevant data will be excluded); the second was that the sample would be broadened to include other forms of text than the news articles that had been identified in Mediearkivet. In total, approximately 200 texts have been included in the analysis. The sample is far from exhaustive with regard to published articles or other forms of texts that include statements made by the companies in defence of their businesses. Nonetheless, the texts that have been analysed constitute a robust documentation of statements made by the two companies following the allegations of criminal activities.

The analysis has been conducted in two stages. In the first, the companies' defence strategies and the framing of these strategies have been analysed on the basis of Cohen's theoretical framework with a focus on the appeal to higher loyalties. We ask how the companies have defended themselves against allegations of criminal activity. How are language, key concepts and categories used to frame the companies' statements? In the second stage of the analysis, the corporate framings have been located in a social context, with the point of departure being that the way issues are framed is grounded in social structures. We present our findings in the next section.

\section{The corporate accounts}

The public image of Lundin Petroleum and TeliaSonera was significantly impaired by the allegations of criminal activities. Following the disclosures, the companies were under considerable pressure from both the media and the public to defend themselves against the accusations. Several of the forms of denial identified by Cohen [6] in a context of gross human rights violations have also been identified in the responses of the Swedish corporations examined in the current study. The aim of these accounts can be understood as having been to present legitimisations in order to re-establish social acceptance for the businesses. The accounts focused on refuting the allegations of criminal activity, vindicating the companies' activities in the regions concerned and legitimising the relevant industries as a whole.

In the introduction to this paper we asked in what ways the two companies accused of crimes appeal to higher loyalties, and how the Swedish social and cultural context might affect the ways in which this particular defence mechanism is used. First, we will explore the corporate appeals to a higher loyalty, which in this context takes the form of responsible capitalism. Second, we examine post-colonial tendencies embedded in this appeal to higher loyalties. 


\section{Appealing to a higher loyalty - responsible capitalism}

The accounts used by the representatives of the two corporations may, to use Cohen's [6] terminology, be interpreted as forms of interpretative denial. The CEO of TeliaSonera responded to the accusations by stating, "I've said it before and I'll say it again: TeliaSonera has not bribed anyone" [44] and the chairman of the Board of Lundin Petroleum commented on the accusations by stating that "...there has not been any proof, there is no substance at all" [45]. In some sense, these and similar accounts by the corporations could have been interpreted as constituting examples of literal denial since the accusations of crime are denied. However, the events themselves are not denied - neither the business deal in Uzbekistan nor the oil explorations conducted at the time of the conflict in Sudan. Instead, what we can see here, in Cohen's terms, is a denial of responsibility, a form of interpretative denial, which functions as a way of neutralising intent and responsibility. In the case of TeliaSonera, the company denied that the transactions could be perceived as a bribe and also denied any connection with the president in Uzbekistan. In the case of Lundin Petroleum, the company denied that its presence in the region had any negative effect on the conflict in Sudan (and instead claimed that it had a positive effect, as will be discussed below). In addition, Lundin Petroleum used what Cohen [6] would describe as a denial of knowledge, as a form of interpretative denial, that refers to assertions of not having known what was happening at the time. The following statement, in which the chairman of the Board of Lundin Petroleum commented on the report by ECOS [28] in relation to crimes against humanity in Sudan, could be interpreted as a form of denial of knowledge: “...I have definitely not seen any of the mass expulsions that are being talked about. I wonder whether those who have written the report have really been there and seen how things are." [46].

In the case of Lundin Petroleum, the very clear denials of the corporation's involvement in the alleged crimes were persistent over the time period studied. When it comes to TeliaSonera, a change in the accounts that were used becomes visible following the replacement of the CEO and certain members of the board of directors. Thereafter, the new representatives started to distance the company from its former leaders, framing the responsibility as lying with a small number of managers who no longer worked for the company. The new chairman of the board of TeliaSonera described these former mangers in the following way: "Even if people have been thinking of the company's best interests, our assessment is that poor judgement has been shown in relation to acquisitions made in a number of markets in Eurasia" [47]. The statement can be interpreted as constituting a form of denial of responsibility by creating a scapegoat, and in this way trying to create the opportunity for a fresh start for TeliaSonera as a company.

The crimes that the companies have been accused of are closely related to their presence in the regions in question, and this fact is not deniable. Journalists and human rights organisations have portrayed the crimes, particularly those related to corruption in Uzbekistan, but also to some extent Lundin Petroleum's involvement in crimes against humanity as a result of its oil exploitation in Sudan, as being a more or less inevitable result of doing business in these countries. Thus, the representatives of the corporations have also had to defend why they were doing business in these regions. 
Here, interpretative denial is expressed simultaneously with implicatory denial, which can involve the justification of an event by referring to a higher loyalty [4, 6]. The most obvious appeals to higher loyalties for businesses would involve profit maximisation and economic interests. However, as we will show, another form of appeal to higher loyalties is more apparent here, namely a quasiphilanthropic argument in which the corporations emphasised the societal benefits associated with their business activities. Representatives of both companies expressed that they were proud of their company and of what they had managed to achieve for people in the regions in which they had been operating. This form of righteous argument can be seen in the following statement, in which a representative of Lundin Petroleum described the company as a responsible actor:

"I am convinced that these countries need investors, such as Lundin Petroleum, that are responsible and that invest in a way that is sustainable over the long term. The only chance for these countries to resolve the problems they face is through economic growth" [48].

In another statement, Lundin Petroleum described their operations in Sudan as a "force for good" that "contribute[d] to the improvement of the lives of the people of Sudan" [49]. Instead of highlighting profit maximisation, the Swedish companies chose to highlight their social responsibility as a means of gaining credibility. However, in the texts that were primarily addressed to shareholders, profit-making can be discerned as constituting the core value of the operations in question. For example, Ian Lundin made the following statement in an open Letter to the shareholders: "At all times our objective in Africa has been to find oil and gas in the most sound and efficient manner but always being responsible from a social and environmental perspective" [50]. This self-presentation can be interpreted within a frame of responsible capitalism, the idea of pursuing both profit and social good in a competitive free market in a globalised economy, a form of appeal to higher loyalties for corporations wanting to appear responsible. In a similar manner, TeliaSonera framed its aim to maximise profits as part of a primary mission to do good:

"The operations [in Central Asia] have made a powerful contribution to the group's growth and profitability, and foreign investments in infrastructure have played an important part in the modernisation of these countries following the collapse of the Soviet Union" [51].

TeliaSonera's business in Central Asia was thus portrayed as contributing to the development of democracy and human rights. When questions were asked about whether TeliaSonera should withdraw from these "risky markets" in Central Asia, the company chose to underline human rights issues:

"Leaving countries is a difficult issue, that can also have consequences for human rights in the country in question. ... [W] e believe that the best thing we can do appears to be to stay" [52]. 
Instead of withdrawing, the company would do more good by strengthening its presence in Central Asia. The accounts employed by the corporations, which framed their businesses as responsible corporations, may function as a way of avoiding moral censure. The corporations attempted to frame themselves as being engaged in "good corporate citizenship" (see [53]). This was expressed quite distinctly by the communications manager of Lundin Petroleum in a newspaper interview: "We have tried to strive to be good citizens" [54]. By their use of this framing, the corporations aimed to transform the accusations of crime into an opportunity to describe the companies as being responsible and providing opportunities for development in the countries in which they were operating. Similar techniques of neutralisation can be found in Huisman's [7] analysis of the rationalisations employed by corporations involved in international crimes, which also involve emphasising the positive effects of their presence in the region. In this sense, the defence mechanisms employed by Swedish corporations constitute part of a global public discourse on businesses, the conditions for business activity and corporate responsibility - the higher loyalty. Another aspect of this that will be further discussed below is that of how the appeal to a higher loyalty might be interpreted within a post-colonial discourse, and how the Swedish social and cultural context might affect the ways in which this defence mechanism is used.

\section{Post-colonial tendencies - contributing to development, democracy and peace}

Among other things, post-colonial theory has demonstrated how the language of colonialism still shapes western ideas about other parts of the world. It has also criticised the assumption that countries of the global North can "solve development ' problems" " ([38], p. 27). The notion of "exporting civilisations" from the global North to the global South has been an important part of colonialism [36, 38]. In the same tradition and self-image, the Swedish corporations chose to frame their exploitation of foreign markets as a civilising mission. Consider the following statement by the former foreign minister of Sweden, Carl Bildt, who was a member of the board of Lundin Petroleum for a time:

"I believe that when you have a presence, when they (the regimes) have western eyes on them, whether it's aid workers, companies or something else, then you're helping the people in these areas. Violations don't occur there" [55].

In this quote, "western eyes" are referred to as constituting a protection against abuses and violations of human rights. This form of framing not only denies the brutal experiences of colonialism, but also constructs an image of what is "western" as being something more civilised (than the "non-western") (see [38], p. 128ff). The following example shows how one of the board of directors of Lundin Petroleum also expressed an understanding of "western" corporations as being better than "non-western" corporations, in this case Chinese companies:

"If the oil industry were only to do business with democracies, you'd be cycling to work. Imagine being without oil from Saudi Arabia, Qatar, Iran or Venezuela. 
In the case of Sudan, I believe we have helped the country to achieve stability. Our reasoning was that if we aren't there, someone else will be. Is it better that it's the Chinese? I don't believe you can allow these countries to end up in the hands of ruthless people - and the Chinese are ruthless" [56].

This type of framing enables the business both to appear to be doing something good, in the sense of providing oil (by arguing that we would otherwise have to cycle to work), and to appear to be a good and responsible investor (in contrast to the Chinese) (see [7] for similar finding). Another form of significant account involves the framing of the companies as "helpers" that enable social progress and improve people's lives in the areas in which they operate. This framing can be seen in the quote above but is even more apparent in a debate article authored by the Lundin brothers, in which they defended their business by referring to how they had helped the Sudanese people:

"The wealth that has been created as a result of the Lundin group's oil and mining projects has been of benefit to countless men, women and children and will continue to give them the chance of a better life. ... In areas that are subject to extreme poverty, economic development has to be initiated with the help of foreign investments in infrastructure and the development of natural resources" [46].

Here the exploration for oil is described as a mission to provide help. The corporation thus framed its operations in Sudan in a narrative in which economic development is synonymous with foreign investment: "You have to help these countries develop their natural resources, because natural resources are a catalyst for economic development" [57]. This framing of the business as a mission to provide help was developed even further by framing the business as having contributed to peace in Sudan. In an open letter to the shareholders, Lundin Petroleum stated:

"The Comprehensive Peace Agreement (CPA) signed between the Government of Sudan and the Southern Sudanese representatives in 2005 validated our view that oil could be used to achieve a sustainable peace" [50].

The contribution of oil companies to the peace in Sudan was even more directly expressed in a radio interview with the chairman of the Board of Lundin Petroleum: "You cannot ignore the fact that peace only came after the production of oil had started. So I think that the production of oil in Sudan had an influence on the peace agreement that was signed in 2005" [45].

In a similar manner, statements by TeliaSonera framed the business as having a profoundly beneficial social impact: "Telecommunications are enormously important to both economic development and democratisation" [58]. In an earlier interview for the same newspaper, the newly elected chairman of the board of TeliaSonera had referred to the UN millennium goals of decreasing poverty as a means of situating the business in a frame in which telecommunications were portrayed as producing economic development [59]. 
While Lundin Petroleum framed its business activities as contributing to the peace agreement in Sudan, TeliaSonera's business in Uzbekistan was framed against the backdrop of the Arab Spring:

"Five years ago we invested in a licence to provide telecom services in Uzbekistan. Why did we do so? First and foremost in order to create growth and value for our shareholders, but that was not the only reason. We at TeliaSonera would argue that telecommunications are a power for good. Everyone who has followed the far-reaching developments witnessed during the Arab Spring will understand what we mean. It is an irrefutable fact that modern telecommunications play an important role when a country starts along this long journey towards democracy" [44].

The accounts presented here may be interpreted as attempts to bolster and defend the legitimisation of the corporation and its public image. The corporations frame their exploitation of foreign markets as a civilising mission. These framings constitute part of a larger public discourse on businesses in which foreign investment is assumed to contribute to development, democracy and peace in "developing countries". While telling the story of how TeliaSonera had made sure "that one-third of the population of Uzbekistan uses TeliaSonera's network to surf and read and to be able to hear about what is happening in the world", the CEO of the time expressed how proud he was of the "Nordic company with the values we have" [60]. In their statements, the corporations make use of well-known discourses that emphasise Swedish or Nordic generosity, helpfulness and decency. Framing a company as a friendly corporation (which is understood as being the opposite of exploitative) is very much in line with the image of the Nordic countries as representing "the good helper" (see [37], p. 76).

\section{Conclusions}

The analysis of the accounts employed by TeliaSonera and Lundin Petroleum when defending themselves against allegations of crime indicates a certain form of appeal to higher loyalties. To justify their business activities, the corporations employed rationalisations that referred to the societal benefits associated with their activities in the regions in which they were operating. Our material shows a somewhat ambiguous argumentation on the part of the two companies. On the one hand, their underlying arguments focus on creating good profitability and returns for the company's owners on the basis of the premises of the free market economy, "business as usual". On the other hand, they focus on contributing to wealth creation and encouraging democracy in the countries in which they operate, which we have labelled the quasi-philanthropic argument. By closing their eyes to the potential conflict that these arguments contain, they succeeded in producing a causal chain whereby the inherent dynamics of the market, with their demands for profitability, in principle automatically result in producing wealth and improving democracy, along with respect for human rights and civil liberties. Our material provides a range of evidence to support this view. Clear examples can be seen in Lundin Petroleum's arguments that oil production in the Sudan contributed to producing peace in the country [45], and in TeliaSonera's statement that the establishment of profitable telecommunications was enormously 
important to the democratisation of Uzbekistan [58]. This quasi-philanthropic form of argumentation claims that profitable entrepreneurial activities constitute the means of achieving the goals of democracy and prosperity. It is important to appear to be responsible capitalists, with profit-maximisation being legitimised, and thereby also in part overshadowed, by the righteous objective of contributing to the development of democracy. Following the reasoning of Tombs and Whyte [9], these type of framings are nothing other than new techniques to promote profit-maximisation. The material also shows that this view of responsible capitalists refers to western capitalism in general and to Swedish capitalism in particular, as can be seen by the distinction made in relation to the "ruthless Chinese" [56]. The way the defence strategies are framed ties in to a public understanding of Sweden and its corporations as providing social justice and human rights (see [35]). Thus, the findings indicate that the specific defence mechanisms that are employed are embedded in a social and cultural context in which defence strategies include framing a business as helping the people and the countries in which it operates and emphasising a corporation's "Nordic values" by linking into a post-colonial discourse. This self-presentation of the responsible Swedish capitalist is of major importance to the maintenance of a positive view of the brand. At the same time, the use of this ambiguous argumentation conceals the fact that the corporations' primary objective was actually that which the companies' statements presented as the means: the establishment of profitable operations. Democracy and respect for human rights and civil liberties are not goals that are given a high priority per se, but are rather a possible side effect of companies' goodwill. The idea of such companies engaging in operations that contribute to improving levels of respect for human rights without at the same time producing economic returns for shareholders does not fit with the logic of "business as usual".

\section{Compliance with ethical standards}

Funding The work with this article has been conducted within the context of the project "Business as usual. Corporate strategies in response to allegations of crime", financed by Riksbankens Jubileumsfond (RJ P150176:1) and by Anna Ahlström and Ellen Terserus Foundation.

Open Access This article is distributed under the terms of the Creative Commons Attribution 4.0 International License (http://creativecommons.org/licenses/by/4.0/), which permits unrestricted use, distribution, and reproduction in any medium, provided you give appropriate credit to the original author(s) and the source, provide a link to the Creative Commons license, and indicate if changes were made.

\section{References}

1. Lynch, M. J. (1990). The Greening of Criminology: A Perspective for the 1990s. The Critical Criminologist (2,3), 3-4,11-12.

2. Michalowski, R. J., \& Kramer, R. C. (Eds.) (2006). State-Corporate Crime: Wrongdoing at the Intersection of Business and Government. Piscataway, NJ: Rutgers University Press.

3. South, N., \& Beirne, P. (2006). Green criminology. In Aldershot, England. Burlington, VT: Ashgate.

4. Cohen, S. (1996). Government responses to human rights reports: claims, denials, and counterclaims. Human Rights Quarterly, 18(3), 517-543.

5. Cohen, S. (2000). Human rights and crimes of the state: the culture of denial. In J. Muncie, E. McLaughlin, \& M. Langan (Eds.), Criminological perspectives. A reader (pp. 489-507). London: Sage Publications. 
6. Cohen, S. (2009). States of denial. Knowing about atrocities and suffering. Cambridge: Polity Press.

7. Huisman, W. (2010). Business as Usual? Corporate Involvement in International Crimes. Hague: Eleven International Publishing.

8. Ruggie, J. G. (2013). Just business: multinational corporations and human rights. New York: W. W. Norton \& Co..

9. Tombs, S., \& Whyte, D. (2015). The corporate criminal: why corporations must be abolished. Abingdon: Routledge.

10. Scott, M. B., \& Lyman, S. M. (1968). Accounts. American Sociological Review, 33(1), 46-62.

11. Silander, D. (2007). Tillståndet för mänskliga rättigheter i Sverige. In A. Staaf \& L. Zanderi (Eds.), Mänskliga rättigheter $i$ svenska belysning (pp. 72-87). Malmö: Liber.

12. Sutherland, E. H. (1949). White collar crime. New York: Dryden Press.

13. Braithwaite, J. (1984). Corporate crime in the pharmaceutical industry. London: Routledge \& Kegan Paul.

14. Coleman, J. W. (1985). The criminal elite: the sociology of white collar crime. New York: St. Martin's Press.

15. Pearce, F. (1976). Crimes of the powerful: Marxism, crime, and deviance. London: Pluto Press.

16. Chandler, G. (2003). The evolution of the business and human rights debate. In R. Sullivan (Ed.), Business and human rights: dilemmas and solutions (pp. 22-31). Sheffield: Greenleaf.

17. Clinard, M. B., \& Yeager, P. C. (1980). Corporate crime. New York: Free Press.

18. Friedrichs, D. O. (2007). Trusted Criminals: White Collar Crime in Contemporary Society (3rd. ed.). Belmont, CA: Cengage Learning.

19. Slapper, G., \& Tombs, S. (1999). Corporate crime. Harlow: Longman.

20. Benson, M. L. (1985). Denying the guilty mind: accounting for involvement in a white-collar crime. Criminology, 23(4), 583-607.

21. Vieraitis, L. M., Piquero, N. L., Piquero, A. R., Tibbetts, S. G., \& Blankenship, M. (2012). Do women and men differ in their neutralizations of corporate crime? Criminal Justice Review, 37(4), 478-493.

22. Benoit, W. L. (1995). Accounts, Excuses, and Apologies. New York: State University of New York Press.

23. Mathiesen, T. (2004). Silently Silenced: Essays on the Creation of Acquiesence in Modern Society. Hook: Waterside Press.

24. Whyte, D. (2012). Between crime and Doxa:researching the worlds of state-corporate elites. State Crime Journal, 1(1), 88-108.

25. Amnesty International. (2000). Sudan: The Human Price of Oil., https:/www.amnesty.org/en/documents/ AFR54/001/2000/en/, Accessed 12 November 2015.

26. Christian Aid. (2001). Scorched Earth, Oil and War in Sudan, http://postconflict.unep.ch/sudanreport/ sudan_website/doccatcher/data/documents/The\%20scorched\%20earth.pdf, Accessed 12 November 2015.

27. Human Rights Watch. (2003). Sudan Oil Companies Complicit in Rights Abuses. https://www.hrw.org/ reports/2003/sudan1103/, Accessed 15 November 2015.

28. ECOS. (2010). Unpaid debt - the legacy of lundin in block 5 a, Sudan 1997-2003. http://www.ecosonline. org/reports/2010/UNPAID_DEBT fullreportweb.pdf, Accessed 12 November 2015.

29. Swedish Prosecution Authority. (2010). Pressmeddelande: Förundersökning om folkrättsbrott http://www. mynewsdesk.com/se/pressreleases/foerundersoekning-om-folkraettsbrott-427749, Accessed 7 April, 2016

30. Transparency International. (2015). 2015 Corruption Perceptions Index. http://www.transparency.org/ cpi2015\#downloads. Accessed 22 Feb, 2016.

31. Human Rights Watch. (2015). World Report 2015: Uzbekistan. https://www.hrw.org/world-report/2015/ country-chapters/uzbekistan, Accessed 22 February 2015.

32. Uppdrag granskning. (2012). Teliasonera i miljardaffär med diktatur. http://www.svt.se/ug/teliasoneragjorde-miljardaffar-med-diktatur-genom-bolag-i-skatteparadis, Accessed 15 November 2015.

33. Sykes, G. M., \& Matza, D. (1957). Techniques of neutralization: a theory of delinquency. American Sociological Review, 22(6), 664-670.

34. Lundberg, U., \& Tydén, M. (2010). In search of the Swedish model. Contested historiography. In H. Mattsson \& S.-O. Wallensten (Eds.), Swedish Modernism. Architecture, Consumption and the Welfare State (pp. 36-49). London: Black dog publishing.

35. Mulinari, D., \& Räthzel, N. (2009). The promise of the "Nordic" and its reality in the south: the experiences of Mexican workers as members of the 'Volvo Family'. In S. Keskinen, S. Touri, S. Irni, \& D. Mulinari (Eds.), Complying with colonialism: gender, race and ethnicity in the Nordic region. Aldershot: Ashgate.

36. Mulinari, D., Keskinen, S., Irni, S., \& Touri, S. (2009). Introduction: Postcolonialism and the Nordic models of welfare and gender. In S. Keskinen, S. Touri, S. Irni, \& D. Mulinari (Eds.), Complying with colonialism: gender, race and ethnicity in the Nordic region (pp. 16-43). Aldershot: Ashgate. 
37. Palmberg, M. (2009). The Nordic colonial mind. In S. Keskinen, S. Touri, S. Irni, \& D. Mulinari (Eds.), Complying with colonialism: gender, race and ethnicity in the Nordic region (pp. 75-104). Aldershot: Ashgate.

38. McEwan, C. (2009). Postcolonialism and development. London: Routledge.

39. Goffman, E. (1974). Frame analysis: an essay on the organization of experience. Cambridge, Mass.: Harvard U. P.

40. Koenig, T. (2006). Compounding mixed-methods problems in frame analysis through comparative research. Qualitative Research, 6(1), 61-76.

41. Schön, D. A., \& Rein, M. (1994). Frame reflection: toward the resolution of intractable policy controversies. New York, N.Y.: BasicBooks.

42. Bacchi, C. (1999). Women, policy and politics: the construction of policy problems. London: SAGE.

43. Bacchi, C. (2005). Discourse, discourse everywhere: subject "agency" in feminist discourse methodology. NORA: Nordic Journal of Women's Studies, 13(3), 198-209.

44. TeliaSonera. (2012). Press conference 2012-10-17, Lars Nyberg - inledande kommentarer, Kv 3, http:// www.teliasonera.com/sv/newsroom/pressmeddelanden/9591/10/teliasonera-januari-september-20122012/. Accessed 7 April, 2016.

45. Sveriges Radio. (2012b). Ian Lundin bemöter kritiken mot oljejakten i Sydsudan, 2012-03-21, http:// sverigesradio.se/sida/artikel.aspx?programid=1650\&artikel=5026792, Accessed 12 November, 2015.

46. Dagens Nyheter. (2012). Lundin Petroleum: "Anklagelserna mot oss stämmer inte", 2012-03-21.

47. Dagens Industri. (2013a). Därför fick Teliatopparna gå, 2013-11-29.

48. Svenska Dagbladet. (2014). "Vi har alltid varit goda medborgare", 2014-02-24.

49. Lundin Petroleum. (2015). Lundin Petroleum's past activities in Sudan. https://www.lundin-petroleum. com/eng/sudan.php, Accessed 13 November 2015.

50. Lundin Petroleum. (2010). Open Letter to Lundin Petroleum's Shareholders, June 8th 2010 https://www. lundin-petroleum.com/Documents/cr_open_letter_08-06-10_e.pdf, Accessed 7 April, 2016

51. TeliaSonera. (2013). Uttalande av styrelsen med anledning av den externa granskningen av TeliaSoneras investeringar i Uzbekistan, Press release 2013-02-01 http://www.teliasonera.com/sv/newsroom/ pressmeddelanden/2013/2/uttalande-av-styrelsen-med-anledning-av-den-externa-granskningen-avteliasoneras-investeringar-i-uzbekistan/. Accessed 7 April, 2016.

52. Tidningarnas Telegrambyrå. (2013). Ehrling: Telia jobbar på bättring, 2013-06-04.

53. Shamir, R. (2011). Socially responsible private regulation: world-culture or world-capitalism? Law \& Society Review, 45(2), 313-336.

54. Dagens Nyheter. (2011). "Vår närvaro var positiv", 2011-01-07.

55. SVT. (2007). Bildt förnekade jäv i KU-förhör, 2007-04-17, http://www.svt.se/nyheter/inrikes/bildtfornekade-jav-i-ku-forhor. Accessed 7 April, 2016

56. Veckans Affärer. (2011). Hemma hos - Diktatorns vän, 2011-10-27.

57. Aktiespararna. (2012). Stora analysdagen. Interview with Ian Lundin, https://www.youtube.com/watch? v=-mvhAQxdt8c, Accessed 12 November 2015.

58. Dagens Industri. (2013b). Ehrlings svar făr godkänt, 2013-06-05.

59. Dagens Industri. (2013c). Hon rivstartar översyn av Telia. Utmaningarna många för bolagets nya ordförande, 2013-04-04.

60. Sveriges Radio. (2012a). Hör Telia Soneras vd efter nytt avslöjande, 2012-09-20. http://sverigesradio.se/ sida/artikel.aspx?programid=1650artikel=5277218, Accessed 7 April, 2016 